\title{
Association of Polymorphisms in Genes Involved in One-Carbon Metabolism with MTHFR Methylation Levels
}

\author{
Fabio Coppedè ${ }^{1, *}$, Andrea Stoccoro ${ }^{1}\left(\mathbb{D}\right.$, Pierpaola Tannorella ${ }^{1,2}$, Roberta Gallo ${ }^{1,3}$, \\ Vanessa Nicolì $^{1,3}$ and Lucia Migliore ${ }^{1}$ \\ 1 Department of Translational Research and of New Surgical and Medical Technologies, University of Pisa, \\ Via Roma 55, 56126 Pisa, Italy \\ 2 Unit of Genetics of Neurodegenerative and Metabolic Diseases, Fondazione IRCCS Istituto Neurologico \\ Carlo Besta, 20133 Milan, Italy \\ 3 Doctoral School in Genetics, Oncology and Clinical Medicine, Department of Medical Biotechnologies, \\ University of Siena, 53100 Siena, Italy \\ * Correspondence: fabio.coppede@med.unipi.it; Tel.: +39-050-2218544
}

Received: 27 June 2019; Accepted: 30 July 2019; Published: 31 July 2019

\begin{abstract}
Methylenetetrahydrofolate reductase (MTHFR) is a pivotal enzyme in the one-carbon metabolism, a metabolic pathway required for DNA synthesis and methylation reactions. MTHFR hypermethylation, resulting in reduced gene expression, can contribute to several human disorders, but little is still known about the factors that regulate MTHFR methylation levels. We performed the present study to investigate if common polymorphisms in one-carbon metabolism genes contribute to MTHFR methylation levels. MTHFR methylation was assessed in peripheral blood DNA samples from 206 healthy subjects with methylation-sensitive high-resolution melting (MS-HRM); genotyping was performed for MTHFR 677C $>\mathrm{T}$ (rs1801133) and 1298A $>\mathrm{C}$ (rs1801131), MTRR 66A $>\mathrm{G}(\mathrm{rs} 1801394)$, MTR 2756A >G (rs1805087), SLC19A1 (RFC1) 80G>A (rs1051266), TYMS 28-bp tandem repeats (rs34743033) and 1494 6-bp ins/del (rs34489327), DNMT3A -448A>G (rs1550117), and DNMT3B $-149 \mathrm{C}>\mathrm{T}$ (rs2424913) polymorphisms. We observed a statistically significant effect of the DNMT3B $-149 \mathrm{C}>\mathrm{T}$ polymorphism on mean MTHFR methylation levels, and particularly CT and TT carriers showed increased methylation levels than CC carriers. The present study revealed an association between a functional polymorphism of DNMT3B and MTHFR methylation levels that could be of relevance in those disorders, such as inborn defects, metabolic disorders and cancer, that have been linked to impaired DNA methylation.
\end{abstract}

Keywords: methylenetetrahydrofolate reductase; MTHFR; methylation; one-carbon metabolism; folate metabolism; polymorphisms; DNMT3B; epigenetics

\section{Introduction}

The folate and methionine cycles are the "core" part of the one-carbon metabolism, a set of interconnected pathways that supply methyl groups for the synthesis of nucleic acids, amino acids, and $S$-adenosylmethionine (SAM), the main intracellular methylating agent [1]. Methylenetetrahydrofolate reductase (MTHFR) is a pivotal enzyme in one-carbon metabolism and catalyzes the conversion of 5,10-methylenetetrahydrofolate to 5-methyltetrahydrofolate (5-methylTHF), the main form of circulating folate and the methyl donor for homocysteine (hcy) remethylation to methionine in the reaction catalyzed by methionine synthase (MTR) that transfers the methyl group from 5-methylTHF to hcy, forming tetrahydrofolate (THF) and methionine. Methionine is then used for the production of 
SAM, required for DNA and protein methylation reactions, and THF re-enters the folate pathway as an acceptor of novel one-carbon moieties (Figure 1).

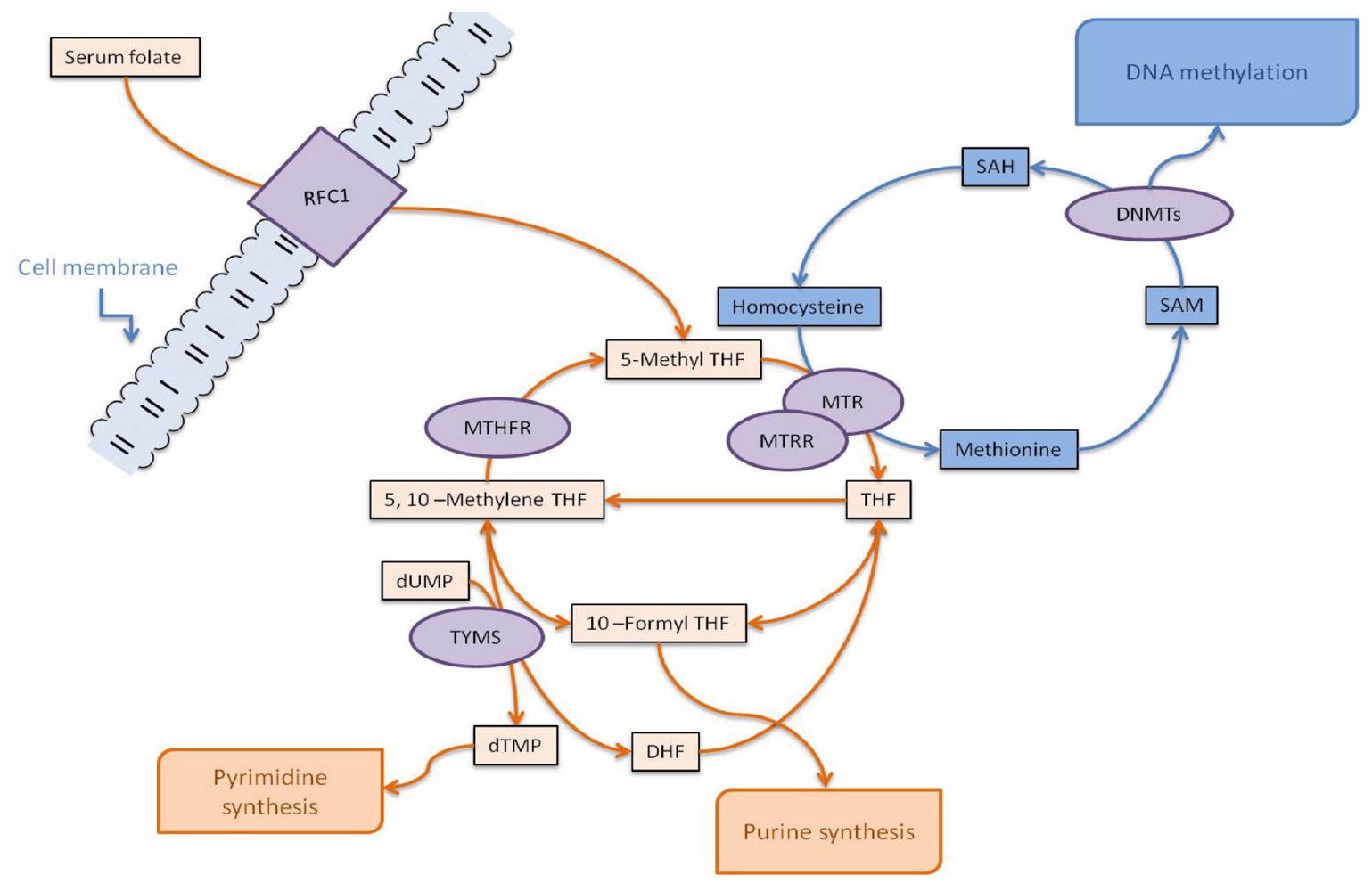

Figure 1. Simplified overview of the folate (orange color) and methionine (blue color) cycles in the one-carbon metabolism, adapted from [1]. The diagram illustrates the enzymes (violet color) whose polymorphisms have been investigated in this article, and their metabolites. Enzymes: DNMTs, DNA methyltransferases; MTHFR, methylenetetrahydrofolate reductase; MTR, methionine synthase; MTRR, methionine synthase reductase; RFC1, reduced folate carrier 1; TYMS, thymidilate synthase. Metabolites: DHF, dihydrofolate; THF, tetrahydrofolate; dTMP, deoxythymidine monophosphate; dUMP, deoxyuridine monophosphate; SAH, S-adenosylhomocysteine; SAM, S-adenosylmethionine.

Rare and severe MTHFR mutations lead to MTHFR deficiency, an autosomal recessive inborn defect characterized by extremely high hcy levels in the urine and plasma, causing developmental delay, eye disorders, thrombosis, and osteoporosis [2]. More common polymorphisms in the MTHFR gene, such as the 677C $>\mathrm{T}$ (rs1801133) and 1298A >C (rs1801131) ones, reduce the enzyme thermostability and activity and can lead to hyperhomocysteinemia, especially in homozygous 677TT carriers [3-5]. These common polymorphisms, and particularly the MTHFR 677C $>\mathrm{T}$ one, have been often associated with a small increase in the risk of various human conditions, including male infertility, pregnancy loss, neural tube defects, congenital heart disease and Down syndrome [6-8], and have been suggested to contribute to complex disorders such as cancer, cardiovascular diseases, autoimmune disorders and neurodegenerative diseases, among others [9-14].

More recent evidence suggests than not only sequence variants, but also epigenetic modifications of the MTHFR gene can contribute to human disorders. Particularly, increased MTHFR promoter methylation results in decreased gene expression levels and has been associated with male infertility, pre-eclampsia, recurrent miscarriages, trisomy 21 and congenital heart disease in the offspring [15-21]. $M T H F R$ hyper-methylation is also suspected to play a role in diabetic complications, vascular diseases and cancer [22-26].

Increasing evidence suggests an association between circulating folate levels and the methylation status of several genes [26-28], and common polymorphisms of genes involved in one-carbon metabolism, including MTHFR 677C $>$ T and 1298A $>C, M T R 2756 \mathrm{~A}>\mathrm{G}$ (rs1805087), methionine synthase 
reductase (MTRR) 66A $>\mathrm{G}$ (rs1801394), thymidilate synthase (TYMS) 28-bp tandem repeat (rs34743033) and 1494 ins/del (rs34489327), reduced folate carrier (SLC19A1 or RFC1) 80G >A (rs1051266), and DNA methyltransferases DNMT3A -448A $>$ G (rs1550117) and DNMT3B -149C > T (rs2424913) ones, have been frequently investigated as potential modulators of either global or gene-specific methylation levels in various human conditions [29-32]. In addition, there is evidence that certain polymorphisms, such as MTR polymorphisms, can act as cis-regulatory elements to regulate the methylation levels of their own gene promoter, as well as trans-regulatory elements to regulate the methylation levels of other metabolic genes [33]. However, little is still known concerning the contribution of common polymorphisms in one-carbon metabolism genes to MTHFR methylation levels.

To further address this issue, in the present study we investigated a cohort of 206 healthy individuals searching for correlation between common polymorphisms in the main genes of one-carbon metabolism and the methylation levels of the MTHFR gene.

\section{Results}

Table 1 shows the demographic characteristics of the study population and the average methylation levels of the MTHFR gene in our cohort. The study was performed in 206 healthy Italian subjects, including 67 males and 137 females of mean age $71.4 \pm 15.4$ years. We investigated a CpG island located in the $5^{\prime}$ untranslated region (5' UTR) of the MTHFR gene, whose methylation levels are inversely correlated with gene expression levels [24,34]. Methylation levels of this region ranged from $5.9 \%$ to $69.3 \%$ in the study population, with an average value of $29.3 \%$, which is in agreement with previous investigations in various populations $[20,24,27,35]$.

Table 1. Study population.

\begin{tabular}{cccc}
\hline Total Subjects & Age (Mean \pm SD) & Gender & MTHFR Methylation (Mean \pm SD) \\
\hline \multirow{2}{*}{206} & $71.4 \pm 15.4$ & M: 67 & $29.3 \pm 9.3 \%$ \\
\hline
\end{tabular}

Table 2 shows the genotype distribution of the investigated polymorphisms in the study population; all the genotype distributions conformed to Hardy-Weinberg equilibrium (HWE) expectations and are in agreement with those previously reported in healthy Caucasians $[5,36,37]$.

Table 2. Distribution of genotypes in the study population.

\begin{tabular}{|c|c|}
\hline Polymorphism & Genotypes: $\mathrm{N}^{\circ}$ of Subjects (\%) \\
\hline MTHFR 677C $>\mathrm{T}$ & CC: 72 (35.0\%), CT: 91 (44.2\%), TT: 43 (20.8\%) \\
\hline MTHFR $1298 \mathrm{~A}>\mathrm{C}$ & AA: $95(46.1 \%)$, AC: $95(46.1 \%)$, CC: $16(7.8 \%)$ \\
\hline MTRR 66A $>\mathrm{G}$ & AA: 61 (29.6\%), AG: 105 (51.0\%), GG: 40 (19.4\%) \\
\hline MTR 2756A $>\mathrm{G}$ & AA: $157(76.2 \%)$, AG: 47 (22.8\%), GG: $2(1.0 \%)$ \\
\hline$R F C-180 \mathrm{G}>\mathrm{A}$ & GG: 62 (30\%), GA: 113 (54.9\%), AA: 31 (15.1\%) \\
\hline TYMS 28bp Repeats & 3R3R: 52 (25.2\%), 3R2R: 108 (52.4\%), 2R2R: 46 (22.4\%) \\
\hline TYMS 1494 6bp ins/del & ins/ins:64 (31.1\%), ins/del: $108(52.4 \%)$, del/del: 34 (16.5\%) \\
\hline DNMT3A -448G >A & GG: $170(82.3 \%)$, GA: $36(17.7 \%)$, AA: $0(0.0 \%)$ \\
\hline DNMT3B $-149 \mathrm{C}>\mathrm{T}$ & CC: 90 (43.7\%), CT: 96 (46.6\%), TT: 20 (9.7\%) \\
\hline
\end{tabular}

The correlation between each of the studied polymorphisms and MTHFR methylation levels is shown in Figure 2. We observed a statistically significant effect of the DNMT3B -149C $>$ T polymorphism on mean MTHFR methylation levels, and in particular, a significant difference between wild-type (CC) and heterozygous (CT) subjects $(27.2 \pm 0.9 \%$ vs. $30.6 \pm 0.9 \%, p=0.02)$, and a significant difference between wild-type (CC) and mutant (TT) subjects ( $27.2 \pm 0.9 \%$ vs. $32.8 \pm 2.0 \%, p=0.03)$, revealing that $M T H F R$ methylation increases significantly with the increasing number of $T$ alleles. None of the other polymorphisms showed a significant contribution to MTHFR methylation levels (Figure 2). 
MTHFR $677 \mathrm{C}>\mathrm{T}$

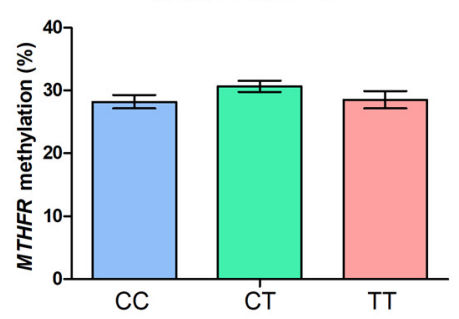

$M T R 2756 \mathrm{~A}>\mathrm{G}$

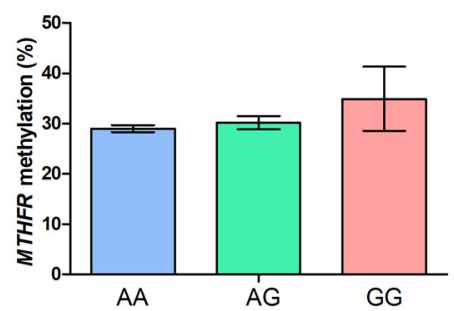

TYMS 1494 6bp ins/del

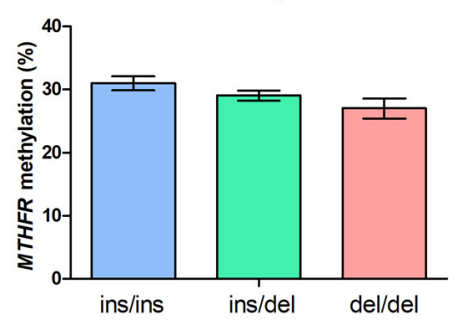

MTHFR 1298A>C

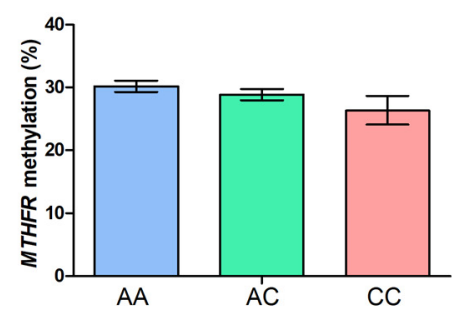

$R F C-180 G>A$

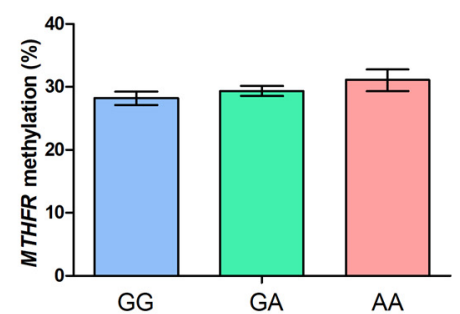

DNMT3A -448G>A

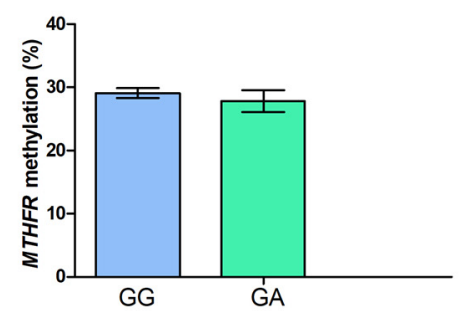

MTRR 66A>G

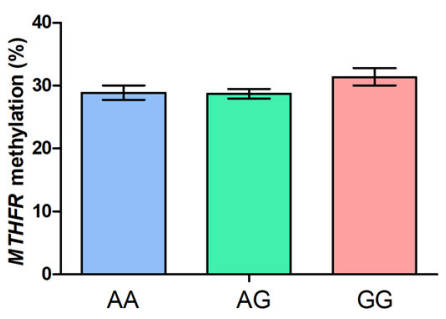

TYMS 28bp Repeats

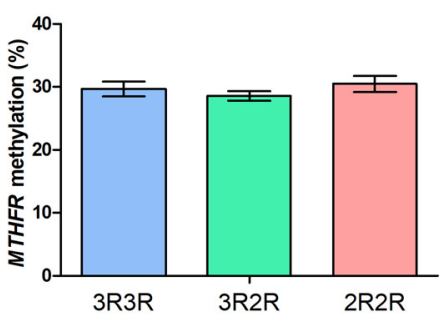

DNMT3B -149C>T

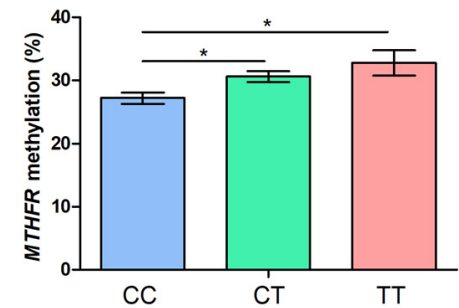

Figure 2. Correlation between one-carbon metabolism gene polymorphisms and MTHFR methylation levels. Data are expressed as means \pm SEM. *Denotes a statistically significant difference after post-hoc Bonferroni's correction for multiple testing $(p<0.05)$.

\section{Discussion}

Increasing evidence suggests that MTHFR hypermethylation represents a risk factor for various human disorders [15-26], but little is still known concerning the genetic factors acting as regulatory elements of MTHFR methylation levels. In the present study we investigated several of the major polymorphisms in one-carbon metabolism genes as potential modulators of MTHFR gene methylation in blood DNA samples from 206 healthy individuals, observing a statistically significant contribution of the DNMT3B $-149 \mathrm{C}>\mathrm{T}$ one. This polymorphism is located 149 base pairs upstream the transcription start site, and the minor $\mathrm{T}$ allele has been associated with increased DNMT3B gene expression levels compared to the major C one [38,39]. DNMT3B is the major de novo DNA methyltransferase expressed and active during the early stages of embryonic development, and is impaired in human diseases with chromosomal and genomic instabilities, including inherited diseases and cancer [40]. Particularly, in vitro studies revealed a 30\% increased promoter activity of the DNMT3B -149T allele with respect to the $C$ one [38]. Similarly, the DNMT3B -149T allele resulted in increased gene expression levels in human pancreatic cancer cells [39]. Therefore, it was suggested that the DNMT3B -149C $>$ T polymorphism increases human cancer risk by increasing DNMT3B gene expression levels resulting in increased promoter methylation and silencing of tumor suppressor genes [38,39]. Indeed, this polymorphism was associated with increased risk of several cancers [40], including lung cancer in smokers [41], prostate and gastric and colorectal cancer in certain populations, albeit with conflicting results [42,43]. 
Furthermore, it was shown that the DNMT3B -149C $>$ T polymorphism was linked to altered methylation levels of cancer related genes, such as hMLH1 and ECAD, in colorectal cancer cells [44].

Folate metabolism is required in all dividing cells for a proper supply of nucleotides, as well as in non-dividing cells such as neurons, for a proper repair of damaged DNA bases and for the regulation of DNA and protein methylation patterns, and therefore most of the folate-related genes are ubiquitously expressed and differentially regulated in human tissues, including blood cells [1]. Particularly, there is an indication that both DNMT3A and DNMT3B are de-methylated and expressed blood cells of healthy individuals [35,45]. Similarly, the MTHFR is expressed in blood cells [46], and the expression levels are inversely regulated by promoter methylation levels, that show a large inter-individual variability $[24,35]$.

Indeed, the contribution of DNMT3B polymorphisms to human disease has been investigated in many other diseases than cancer. For example, increasing evidence suggests that the DNMT3B $-149 \mathrm{C}>\mathrm{T}$ polymorphism, either alone or in haplotype combination with other non-coding DNMT3B polymorphisms, contributes to the maternal risk for having a child with Down syndrome [47-49], and has been associated with an increased risk of prematurity [30], with childhood immune thrombocytopenia [50,51] and autoimmune thyroid disease [52]. The association of the DNMT3B $-149 \mathrm{C}>\mathrm{T}$ polymorphism with neurological and neurodegenerative diseases, either alone or in haplotype combination, is still controversial [53-56].

Present findings linking the DNMT3B $-149 \mathrm{C}>\mathrm{T}$ polymorphism to MTHFR methylation levels are original, and if confirmed in other populations could be of relevance for those conditions characterized by increased MTHFR methylation, and particularly for congenital disorders or cancers associated with DNMT3B polymorphisms. For example, recent studies revealed increased MTHFR methylation as a risk factor for recurrent miscarriages, as well as for Down syndrome and congenital heart disease in the offspring [18,20,21], and MTHFR hyper-methylation was seen in several human cancers [24,25,34,57]. Also, male infertility has been recently linked to a DNMT3B polymorphism in strong linkage with the $-149 \mathrm{C}>\mathrm{T}$ one [58], and several studies suggest association of MTHFR hyper-methylation with male infertility [15-17]. Therefore, a further investigation of the link between DNMT3B polymorphisms and MTHFR methylation levels is warranted in several human disorders.

DNMT3A is the other de novo DNA methyltransferase, and the DNMT3A-448A $>$ G polymorphisms was recently associated with the risk of spontaneous abortion [59], as well as with risk of several cancers [60]; therefore, we decided to investigate its contribution to MTHFR methylation levels, observing no association. To the best of our knowledge, there are no other studies addressing this issue.

Concerning MTHFR $677 \mathrm{C}>\mathrm{T}$ and 1298A $>\mathrm{C}$ polymorphisms, we found no association with MTHFR methylation levels. A previous study performed in 101 epileptic patients treated with valproic acid (VPA) and 68 healthy controls also reported no association of MTHFR 677C $>$ T and 1298A $>C$ polymorphisms with MTHFR gene methylation levels in blood DNA of both groups [61]. Collectively, present and previous data [61] suggest that MTHFR 677C $>\mathrm{T}$ and 1298A $>\mathrm{C}$ polymorphisms are unlikely to act as cis-regulatory modulators of MTHFR gene methylation levels. In that manuscript the authors also investigated the contribution of MTR 2756A $>\mathrm{G}, M T R R$ 66A $>\mathrm{G}$, and RFC-1 80G $>\mathrm{A}$ to MTHFR methylation levels, observing an association of the MTR 2756A $>G$ polymorphism only in epileptic patients treated with VPA, but none of the three polymorphisms was linked to MTHFR methylation levels in healthy controls [61]. In the present investigation we included only healthy individuals not taking drugs or supplements known to affect the epigenome, and present data are in agreement with that previous investigation [61], indicating that MTR 2756A $>\mathrm{G}, M T R R$ 66A $>\mathrm{G}$, and $R F C-180 \mathrm{G}>\mathrm{A}$ polymorphisms are not associated with MTHFR methylation levels in untreated healthy subjects. VPA is a very potent epigenetic drug, exerting anti-cancer and neuro-protective effects by its inhibitory action on proteins that catalyze histone deacetylation [60]. Several recent studies suggest that VPA also induces changes is serum folate and hcy levels, as well changes in the methylation levels of several genes, including MTHFR [59-61]. Therefore, the contribution of polymorphisms in one-carbon 
metabolism genes to global and gene-specific methylation levels might be exacerbated under treatments that globally affect folate metabolism and the epigenome [61-63].

TYMS competes with MTHFR for 5,10-methylenetetrahydrofolate, and the folate pathway can be shifted toward the synthesis of DNA precursors or toward hcy remethylation to methionine, depending on the cell requirements (Figure 1). We previously observed association of TYMS polymorphisms with the methylation levels of tumor suppressor and DNA repair genes in colorectal cancer cells [31], but no previous study investigated the contribution of TYMS polymorphisms to MTHFR gene methylation. However, the present investigation revealed no association of TYMS polymorphisms with MTHFR methylation levels.

In summary, we investigated the contribution of several of the major polymorphisms of genes coding enzymes involved in the folate and methionine cycles of the one-carbon metabolism to MTHFR methylation levels in healthy individuals, observing a significant association of the DNMT -149T allele with increased MTHFR methylation. Additional studies are required to further address this issue in human disorders characterized by MTHFR hyper-methylation, as well as to investigate if drugs or compounds exerting epigenetic properties are able to modulate this association. Of particular interest are disorders such as Down syndrome, lung and gastrointestinal cancers, and male infertility, all linked to DNMT3B variants and characterized by MTHFR hyper-methylation.

\section{Materials and Methods}

\subsection{Study Population}

DNA samples from peripheral leukocytes were available from a total of 206 healthy individuals, including 67 males and 139 females of mean age $71.4 \pm 15.4$ years (Table 1), mainly recruited from 2011 to 2015 as healthy control subjects for genetic and epigenetic case-control investigations [13,20,35]. All the individuals were volunteer subjects of Italian origin, underwent a rigorous clinical and neurological examination, and were healthy at blood drawing. In addition, individuals taking vitamins, drugs, substances or supplements known or suspected to interfere with one-carbon metabolism and DNA methylation reactions, such as anti-cancer drugs, anti-epileptic drugs, anti-inflammatory drugs, epi-drugs, metformin, tobacco smoking, folic acid or other vitamin supplements, were not enrolled in the study. Each subject gave an informed and written consent for the inclusion in the study that received approval from the Ethics Committee of the Pisa University Hospital (Protocol number 3618/2012), and was performed in accordance with the Declaration of Helsinki.

\subsection{Analysis of MTHFR Methylation Levels}

Two hundred nanograms of DNA from each sample have been treated with sodium bisulfite in order to convert un-methylated cytosines into uracil, using the EpiTect Bisulfite Kit (Qiagen, Milan, Italy, Catalog $N^{\circ}$ 59104). Bisulfite conversion was performed simultaneously on all samples in order to avoid potential batch effects, and the bisulfite conversion efficiency was assessed using a sample of completely un-methylated human DNA (Qiagen, Catalog $\mathrm{N}^{\circ} 59568$ ), resulting of $99 \%$ in average. The MTHFR methylation levels have been assessed using a methylation-sensitive high-resolution melting (MS-HRM) protocol previously developed in our laboratory, validated by pyrosequencing, and fully described by us elsewhere [32]. All the MS-HRM analyses were performed using a CFX96 Real-Time PCR detection system (Bio-Rad, Milan, Italy). Particularly, we studied a CpG island in the $5^{\prime}$-untranslated (UTR) region of the MTHFR gene spanning from +30 to +184 from the transcription start site, and containing $7 \mathrm{CpG}$ sites whose methylation levels were found to be inversely correlated with MTHFR gene expression levels by several authors [24,34]. Table 3 shows the sequence of the primers, the annealing temperature $\left(T_{\mathrm{a}}\right)$, the studied region, the length of the amplicon, and the number of CpG sites within it. Each reaction was performed in duplicate, and we analyzed $10 \%$ of the samples independently on separate occasions to verify the inter-assay variability. Fully methylated and un-methylated DNA (EpiTectH methylated and unmethylated human control DNA, bisulfite 
converted, Qiagen, Catalog $\mathrm{N}^{\circ}$ 59695) were mixed to obtain the following ratios of methylation: $0 \%$, $12,5 \%, 25 \%, 50 \%, 75 \%, 100 \%$. Standard DNA samples with known methylation ratios were included in each assay in order to generate standard curves that were used to deduce the methylation levels of each sample, using an interpolation method previously described [64].

Table 3. Sequence of the primers, annealing temperature $\left(T_{\mathrm{a}}\right)$, length of the amplicon, studied region and number of $\mathrm{CPG}$ sites.

\begin{tabular}{ccccc}
\hline Primer Sequences & $T_{\mathbf{a}}$ & Amplicon Lenght & Region & CpG Sites \\
\hline F: $5^{\prime}$-TTTTAATTTTTGTTTGGAGGGTAGT-3' & \multirow{2}{*}{$54^{\circ} \mathrm{C}$} & $155 \mathrm{bp}$ & From +30 to +184 & 7 \\
R: $5^{\prime}$-AAAAAAACCACTTATCACCAAATTC-3 & & & & 7 \\
\hline
\end{tabular}

\subsection{Analysis of Common Polymorphisms in One-Carbon Metabolism Genes}

Genotyping for MTHFR 677C >T (rs1801133), MTHFR 1298A>C (rs1801131), MTRR 66A >G (rs1801394), MTR 2756A $>$ G (rs1805087), SLC19A1 (RFC-1) 80G >A (rs1051266), TYMS 28-bp repeats (rs34743033), TYMS 1494 6-bp ins/del (rs34489327), DNMT3A -448A >G (rs1550117), and DNMT3B -149C > T (rs2424913) polymorphisms was performed by PCR/RFLP techniques as detailed elsewhere $[36,65]$.

\subsection{Statistical Analysis}

To verify that genotype frequencies of all the studied polymorphisms were in Hardy-Weinberg equilibrium we used the Chi-square $\left(\mathrm{X}^{2}\right)$ analysis. MTHFR methylation data were tested for normality using the Shapiro-Wilk test and showed a normal distribution in our cohort. Multi-factor analysis of variance (ANOVA) including age at sampling, gender, and all the other investigated polymorphisms as covariates, was used to investigate the contribution of each studied polymorphism to MTHFR methylation levels, followed by post-hoc Bonferroni's correction for multiple testing. Statistical analyses were performed with the STATGRAPHICS 5.1 plus software package for Windows, and Bonferroni's corrected $p$-values $<0.05$ were considered statistically significant.

Author Contributions: Conceptualization, F.C.; methodology, P.T., and A.S.; validation, P.T.; formal analysis, F.C., and A.S.; investigation, P.T., A.S., and F.C.; resources, F.C. and L.M.; data curation, V.N., and R.G.; writing-original draft preparation, F.C.; writing-review and editing, F.C.; visualization, F.C.; supervision, F.C., and L.M; project administration, F.C.; funding acquisition, F.C., and L.M.

Funding: This research was funded by the ITALIAN MINISTRY OF HEALTH, grant number GR-2009-1606229 (F.C. Principal Investigator), and the APC was funded by UNIVERSITY OF PISA INTRAMURAL FUNDS.

Acknowledgments: The authors acknowledge all the volunteer subjects that participated to this study and the medical personnel of the Pisa University Hospital that performed their clinical evaluation.

Conflicts of Interest: The authors declare no conflict of interest.

$\begin{array}{ll}\text { Abbreviations } & \\ \text { DNMT } & \text { DNA methyltransferase } \\ \text { HWE } & \text { Hardy-Weinberg equilibrium } \\ \text { MS-HRM } & \text { Methylation-sensitive high-resolution melting } \\ \text { MTHFR } & \text { Methylenetetrahydrofolate reductase } \\ \text { MTR } & \text { Methionine synthase } \\ \text { MTRR } & \text { Methionine synthase reductase } \\ \text { RFC1 } & \text { Reduced folate carrier 1 } \\ \text { SAM } & \text { S-adenosylmethionine } \\ \text { SD } & \text { Standard deviation } \\ \text { SEM } & \text { Mean standard error } \\ \text { THF } & \text { Tetrahydrofolate } \\ \text { TYMS } & \text { Thymidilate synthase } \\ \text { VPA } & \text { Valproic acid }\end{array}$




\section{References}

1. Coppedè, F. The genetics of folate metabolism and maternal risk of birth of a child with Down syndrome and associated congenital heart defects. Front. Genet. 2015, 25, 6-223. [CrossRef] [PubMed]

2. Huemer, M.; Diodato, D.; Martinelli, D.; Olivieri, G.; Blom, H.; Gleich, F.; Kölker, S.; Kožich, V.; Morris, A.A.; Seifert, B.; et al. Phenotype, treatment practice and outcome in the cobalamin-dependent remethylation disorders and MTHFR deficiency: Data from the E-HOD registry. J. Inherit. Metab. Dis. 2019, 42, 333-352. [CrossRef] [PubMed]

3. Shane, B.; Pangilinan, F.; Mills, J.L.; Fan, R.; Gong, T.; Cropp, C.D.; Kim, Y.; Ueland, P.M.; Bailey-Wilson, J.E.; Wilson, A.F.; et al. The $677 \mathrm{C} \rightarrow \mathrm{T}$ variant of MTHFR is the major genetic modifier of biomarkers of folate status in a young, healthy Irish population. Am. J. Clin. Nutr. 2018, 108, 1334-1341. [CrossRef] [PubMed]

4. Nilsson, T.K.; Böttiger, A.K.; Henríquez, P.; Serra Majem, L. MTHFR polymorphisms and serum cobalamin affect plasma homocysteine concentrations differentially in females and males. Mol. Med. Rep. 2014, 10, 2706-2712. [CrossRef] [PubMed]

5. Coppedè, F.; Tannorella, P.; Pezzini, I.; Migheli, F.; Ricci, G.; Caldarazzo lenco, E.; Piaceri, I.; Polini, A.; Nacmias, B.; Monzani, F.; et al. Folate, homocysteine, vitamin B12, and polymorphisms of genes participating in one-carbon metabolism in late-onset Alzheimer's disease patients and healthy controls. Antioxid. Redox Signal. 2012, 17, 195-204. [CrossRef]

6. Gupta, N.; Gupta, S.; Dama, M.; David, A.; Khanna, G.; Khanna, A.; Rajender, S. Strong association of $677 \mathrm{C}>\mathrm{T}$ substitution in the MTHFR gene with male infertility-A study on an indian population and a meta-analysis. PLoS ONE 2011, 6, e22277. [CrossRef]

7. Zhang, Y.; He, X.; Xiong, X.; Chuan, J.; Zhong, L.; Chen, G.; Yu, D. The association between maternal methylenetetrahydrofolate reductase C677T and A1298C polymorphism and birth defects and adverse pregnancy outcomes. Prenat. Diagn. 2019, 39, 3-9. [CrossRef]

8. Zhang, R.; Huo, C.; Wang, X.; Dang, B.; Mu, Y.; Wang, Y. Two Common MTHFR Gene Polymorphisms (C677T and A1298C) and Fetal Congenital Heart Disease Risk: An Updated Meta-Analysis with Trial Sequential Analysis. Cell. Physiol. Biochem. 2018, 45, 2483-2496. [CrossRef]

9. Meneses-Sanchez, P.; Garcia-Hernandez, S.C.; Porchia, L.M.; Pérez-Fuentes, R.; Torres-Rasgado, E.; Del Angel Soto, A.; Gonzalez-Mejia, M.E. C677T and A1298C methylenetetrahydrofolate reductase polymorphisms and breast cancer susceptibility among Latinos: A meta-analysis. Breast Cancer 2019. [CrossRef]

10. Shiao, S.P.K.; Lie, A.; Yu, C.H. Meta-analysis of homocysteine-related factors on the risk of colorectal cancer. Oncotarget 2018, 9, 25681-25697. [CrossRef]

11. Song, Y.; Li, B.; Wang, C.; Wang, P.; Gao, X.; Liu, G. Association between 5,10-Methylenetetrahydrofolate Reductase C677T Gene Polymorphism and Risk of Ischemic Stroke: A Meta-analysis. J. Stroke Cerebrovasc. Dis. 2016, 25, 679-687. [CrossRef]

12. Yuan, Y.; Shao, W.; Li, Y. Associations between C677T and A1298C polymorphisms of MTHFR and susceptibility to rheumatoid arthritis: A systematic review and meta-analysis. Rheumatol. Int. 2017, 37, 557-569. [CrossRef]

13. Stoccoro, A.; Tannorella, P.; Salluzzo, M.G.; Ferri, R.; Romano, C.; Nacmias, B.; Siciliano, G.; Migliore, L.; Coppedè, F. The Methylenetetrahydrofolate Reductase C677T Polymorphism and Risk for Late-Onset Alzheimer's disease: Further Evidence in an Italian Multicenter Study. J. Alzheimers Dis. 2017, 56, 1451-1457. [CrossRef]

14. Liu, L.; Zhang, L.; Guo, L.; Yu, Q.; Li, H.; Teng, J.; Xie, A. MTHFR C677T and A1298C polymorphisms may contribute to the risk of Parkinson's disease: A meta-analysis of 19 studies. Neurosci. Lett. 2018, 662, 339-345. [CrossRef]

15. Khazamipour, N.; Noruzinia, M.; Fatehmanesh, P.; Keyhanee, M.; Pujol, P. MTHFR promoter hypermethylation in testicular biopsies of patients with non-obstructive azoospermia: The role of epigenetics in male infertility. Hum. Reprod. 2009, 24, 2361-2364. [CrossRef]

16. Wu, W.; Shen, O.; Qin, Y.; Niu, X.; Lu, C.; Xia, Y.; Song, L.; Wang, S.; Wang, X. Idiopathic male infertility is strongly associated with aberrant promoter methylation of methylenetetrahydrofolate reductase (MTHFR). PLoS ONE 2010, 5, e13884. [CrossRef] 
17. Rotondo, J.C.; Bosi, S.; Bazzan, E.; Di Domenico, M.; De Mattei, M.; Selvatici, R.; Patella, A.; Marci, R.; Tognon, M.; Martini, F. Methylenetetrahydrofolate reductase gene promoter hypermethylation in semen samples of infertile couples correlates with recurrent spontaneous abortion. Hum. Reprod. 2012, 27, 3632-3638. [CrossRef]

18. Saraswathy, K.N.; Kaur, L.; Talwar, S.; Mishra, J.; Huidrom, S.; Sachdeva, M.P.; Puri, M. Methylenetetrahydrofolate Reductase Gene-specific Methylation and Recurrent Miscarriages: A Case-Control Study from North India. J. Hum. Reprod. Sci. 2018, 11, 142-147. [CrossRef]

19. Ge, J.; Wang, J.; Zhang, F.; Diao, B.; Song, Z.F.; Shan, L.L.; Wang, W.; Cao, H.J.; Li, X.Q. Correlation between MTHFR gene methylation and pre-eclampsia, and its clinical significance. Genet. Mol. Res. 2015, 14, 8021-8028. [CrossRef]

20. Coppedè, F.; Denaro, M.; Tannorella, P.; Migliore, L. Increased MTHFR promoter methylation in mothers of Down syndrome individuals. Mutat. Res. 2016, 787, 1-6. [CrossRef]

21. Asim, A.; Agarwal, S.; Panigrahi, I.; Saiyed, N.; Bakshi, S. MTHFR promoter hypermethylation may lead to congenital heart defects in Down syndrome. Intractable Rare Dis. Res. 2017, 6, 295-298. [CrossRef]

22. Santana Bezerra, H.; Severo de Assis, C.; Dos Santos Nunes, M.K.; Wanderley de Queiroga Evangelista, I.; Modesto Filho, J.; Alves Pegado Gomes, C.N.; Ferreira do Nascimento, R.A.; Pordeus Luna, R.C.; de Carvalho Costa, M.J.; de Oliveira, N.F.P.; et al. The MTHFR promoter hypermethylation pattern associated with the A1298C polymorphism influences lipid parameters and glycemic control in diabetic patients. Diabetol. Metab. Syndr. 2019, 11, 4. [CrossRef]

23. Dos Santos Nunes, M.K.; Silva, A.S.; de Queiroga Evangelista, I.W.; Filho, J.M.; Gomes, C.N.A.P.; do Nascimento, R.A.F.; Luna, R.C.P.; de Carvalho Costa, M.J.; de Oliveira, N.F.P.; Persuhn, D.C. Hypermethylation in the promoter of the MTHFR gene is associated with diabetic complications and biochemical indicators. Diabetol. Metab. Syndr. 2017, 9, 84. [CrossRef]

24. Vaissière, T.; Hung, R.J.; Zaridze, D.; Moukeria, A.; Cuenin, C.; Fasolo, V.; Ferro, G.; Paliwal, A.; Hainaut, P.; Brennan, P.; et al. Quantitative analysis of DNA methylation profiles in lung cancer identifies aberrant DNA methylation of specific genes and its association with gender and cancer risk factors. Cancer Res. 2009, 69, 243-252. [CrossRef]

25. Botezatu, A.; Socolov, D.; Iancu, I.V.; Huica, I.; Plesa, A.; Ungureanu, C.; Anton, G. Methylenetetrahydrofolate reductase (MTHFR) polymorphisms and promoter methylation in cervical oncogenic lesions and cancer. J. Cell. Mol. Med. 2013, 17, 543-549. [CrossRef]

26. Wei, L.K.; Sutherland, H.; Au, A.; Camilleri, E.; Haupt, L.M.; Gan, S.H.; Griffiths, L.R. A potential epigenetic marker mediating serum folate and vitamin B12 levels contributes to the risk of ischemic stroke. Biomed. Res. Int. 2015, 2015, 167976.

27. Grossi, E.; Stoccoro, A.; Tannorella, P.; Migliore, L.; Coppedè, F. Artificial Neural Networks Link One-Carbon Metabolism to Gene-Promoter Methylation in Alzheimer's Disease. J. Alzheimers Dis. 2016, 53, 1517-1522. [CrossRef]

28. Pauwels, S.; Ghosh, M.; Duca, R.C.; Bekaert, B.; Freson, K.; Huybrechts, I.; Langie, S.A.S.; Koppen, G.; Devlieger, R.; Godderis, L. Maternal intake of methyl-group donors affects DNA methylation of metabolic genes in infants. Clin. Epigenet. 2017, 9, 16. [CrossRef]

29. McKay, J.A.; Groom, A.; Potter, C.; Coneyworth, L.J.; Ford, D.; Mathers, J.C.; Relton, C.L. Genetic and non-genetic influences during pregnancy on infant global and site specific DNA methylation: Role for folate gene variants and vitamin B12. PLoS ONE 2012, 7, e33290. [CrossRef]

30. Haggarty, P.; Hoad, G.; Horgan, G.W.; Campbell, D.M. DNA methyltransferase candidate polymorphisms, imprinting methylation, and birth outcome. PLoS ONE 2013, 8, e68896. [CrossRef]

31. Coppedè, F.; Migheli, F.; Lopomo, A.; Failli, A.; Legitimo, A.; Consolini, R.; Fontanini, G.; Sensi, E.; Servadio, A.; Seccia, M.; et al. Gene promoter methylation in colorectal cancer and healthy adjacent mucosa specimens: Correlation with physiological and pathological characteristics, and with biomarkers of one-carbon metabolism. Epigenetics 2014, 9, 621-633. [CrossRef]

32. Llanos, A.A.; Marian, C.; Brasky, T.M.; Dumitrescu, R.G.; Liu, Z.; Mason, J.B.; Makambi, K.H.; Spear, S.L.; Kallakury, B.V.; Freudenheim, J.L.; et al. Associations between genetic variation in one-carbon metabolism and LINE-1 DNA methylation in histologically normal breast tissues. Epigenetics 2015, 10, 727-735. [CrossRef] 
33. Song, M.A.; Brasky, T.M.; Marian, C.; Weng, D.Y.; Taslim, C.; Llanos, A.A.; Dumitrescu, R.G.; Liu, Z.; Mason, J.B.; Spear, S.L.; et al. Genetic variation in one-carbon metabolism in relation to genome-wide DNA methylation in breast tissue from heathy women. Carcinogenesis 2016, 37, 471-480. [CrossRef]

34. Lopomo, A.; Ricciardi, R.; Maestri, M.; De Rosa, A.; Melfi, F.; Lucchi, M.; Mussi, A.; Coppedè, F.; Migliore, L. Gene-Specific Methylation Analysis in Thymomas of Patients with Myasthenia Gravis. Int. J. Mol. Sci. 2016, 17, e2121. [CrossRef]

35. Tannorella, P.; Stoccoro, A.; Tognoni, G.; Petrozzi, L.; Salluzzo, M.G.; Ragalmuto, A.; Siciliano, G.; Haslberger, A.; Bosco, P.; Bonuccelli, U.; et al. Methylation analysis of multiple genes in blood DNA of Alzheimer's disease and healthy individuals. Neurosci. Lett. 2015, 600, 143-147. [CrossRef]

36. Tannorella, P.; Stoccoro, A.; Tognoni, G.; Bonuccelli, U.; Migliore, L.; Coppedè, F. Association study between the DNMT3A $-448 \mathrm{~A}>\mathrm{G}$ polymorphism and risk of Alzheimer's disease in Caucasians of Italian origin. Am. J. Neurodegener. Dis. 2016, 5, 85-93.

37. Giusti, B.; Saracini, C.; Bolli, P.; Magi, A.; Sestini, I.; Sticchi, E.; Pratesi, G.; Pulli, R.; Pratesi, C.; Abbate, R. Genetic analysis of 56 polymorphisms in 17 genes involved in methionine metabolism in patients with abdominal aortic aneurysm. J. Med. Genet. 2008, 45, 721-730. [CrossRef]

38. Shen, H.; Wang, L.; Spitz, M.R.; Hong, W.K.; Mao, L.; Wei, Q. A novel polymorphism in human cytosine DNA-methyltransferase-3B promoter is associated with an increased risk of lung cancer. Cancer Res. 2002, $62,4992-4995$.

39. Xiao, Y.; Word, B.; Hammons, G.; Lyn-Cook, B. Transcriptional activity of DNMT3B in pancreatic cancer cells: Effects of $-149(\mathrm{C} \rightarrow \mathrm{T})$ promoter polymorphism. Biochem. Biophys. Res. Commun. 2011, 415, 220-223. [CrossRef]

40. Gagliardi, M.; Strazzullo, M.; Matarazzo, M.R. DNMT3B Functions: Novel Insights from Human Disease. Front. Cell. Dev. Biol. 2018, 6, 140. [CrossRef]

41. Lai, C.Y.; Huang, C.C.; Tsai, C.H.; Wang, J.Y.; Kerr, C.L.; Chen, Y.Y.; Cai, Y.W.; Wong, R.H. The DNA Methyltransferase 3B -149 Genetic Polymorphism Modulates Lung Cancer Risk from Smoking Asian. Pac. J. Cancer Prev. 2017, 18, 2717-2723.

42. Duan, F.; Cui, S.; Song, C.; Dai, L.; Zhao, X.; Zhang, X. Systematic evaluation of cancer risk associated with DNMT3B polymorphisms. J. Cancer Res. Clin. Oncol. 2015, 141, 1205-1220. [CrossRef]

43. Khoram-Abadi, K.M.; Forat-Yazdi, M.; Kheirandish, S.; Saeidi, N.; Zarezade, Z.; Mehrabi, N.; Neamatzadeh, H. DNMT3B -149 C>T and -579 G>T Polymorphisms and Risk of Gastric and Colorectal Cancer: A Meta-analysis. Asian Pac. J. Cancer Prev. 2016, 17, 3015-3020.

44. Naghibalhossaini, F.; Mokarram, P.; Khalili, E.; Naghibalhossaini, S. DNMT3b -149C/T promoter variants and methylation of colorectal cancer-associated genes. Cancer Biomark. 2015, 15, 227-233. [CrossRef]

45. Rey, R.; Chauvet-Gelinier, J.C.; Suaud-Chagny, M.F.; Ragot, S.; Bonin, B.; d'Amato, T.; Teyssier, J.R. Distinct Expression Pattern of Epigenetic Machinery Genes in Blood Leucocytes and Brain Cortex of Depressive Patients. Mol. Neurobiol. 2019, 56, 4697-4707. [CrossRef]

46. Remuzgo-Martínez, S.; Genre, F.; López-Mejías, R.; Ubilla, B.; Mijares, V.; Pina, T.; Corrales, A.; Blanco, R.; Martín, J.; Llorca, J.; et al. Decreased expression of methylene tetrahydrofolate reductase (MTHFR) gene in patients with rheumatoid arthritis. Clin. Exp. Rheumatol. 2016, 34, 106-110.

47. Coppedè, F.; Bosco, P.; Tannorella, P.; Romano, C.; Antonucci, I.; Stuppia, L.; Romano, C.; Migliore, L. DNMT3B promoter polymorphisms and maternal risk of birth of a child with Down syndrome. Hum. Reprod. 2013, 28, 545-550. [CrossRef]

48. Jaiswal, S.K.; Sukla, K.K.; Kumari, N.; Lakhotia, A.R.; Kumar, A.; Rai, A.K. Maternal risk for down syndrome and polymorphisms in the promoter region of the DNMT3B gene: A case-control study. Birth Defects Res. A Clin. Mol. Teratol. 2015, 103, 299-305. [CrossRef]

49. Moura, C.M.; Bastos, P.R.; Ribeiro, J.S.V.; Ribeiro, M.G.; Amorim, M.R.; Costa-Lima, M.A. DNA (cytosine-5)-methyltransferase 3B (DNMT 3B) polymorphism and risk of Down syndrome offspring. Saudi J. Biol. Sci. 2018, 25, 101-104. [CrossRef]

50. Pesmatzoglou, M.; Lourou, M.; Goulielmos, G.N.; Stiakaki, E. DNA methyltransferase 3B gene promoter and interleukin-1 receptor antagonist polymorphisms in childhood immune thrombocytopenia. Clin. Dev. Immunol. 2012, 2012, 352059. [CrossRef]

51. Gouda, H.M.; Kamel, N.M.; Meshaal, S.S. Association of DNA Methyltransferase 3B Promotor Polymorphism with Childhood Chronic Immune Thrombocytopenia. Lab. Med. 2016, 47, 312-317. [CrossRef] 
52. Cai, T.T.; Zhang, J.; Wang, X.; Song, R.H.; Qin, Q.; Muhali, F.S.; Zhou, J.Z.; Xu, J.; Zhang, J.A. Gene-gene and gene-sex epistatic interactions of DNMT1; DNMT3A and DNMT3B in autoimmune thyroid disease. Endocr. J. 2016, 63, 643-653. [CrossRef]

53. Coppedè, F.; Zitarosa, M.T.; Migheli, F.; Lo Gerfo, A.; Bagnoli, S.; Dardano, A.; Nacmias, B.; Mancuso, M.; Monzani, F.; Siciliano, G.; et al. DNMT3B promoter polymorphisms and risk of late onset Alzheimer's disease. Curr. Alzheimer Res. 2012, 9, 550-554. [CrossRef]

54. Pezzi, J.C.; Ens, C.M.; Borba, E.M.; Schumacher-Schuh, A.F.; de Andrade, F.M.; Chaves, M.L.; Fiegenbaum, M.; Camozzato, A.L. DNA methyltransferase haplotype is associated with Alzheimer's disease. Neurosci. Lett. 2014, 579, 70-74. [CrossRef]

55. Pezzi, J.C.; de Bem, C.M.; da Rocha, T.J.; Schumacher-Schuh, A.F.; Chaves, M.L.; Rieder, C.R.; Hutz, M.H.; Fiegenbaum, M.; Camozzato, A.L. Association between DNA methyltransferase gene polymorphism and Parkinson's disease. Neurosci. Lett. 2017, 639, 146-150. [CrossRef]

56. Pan, H.; Shen, J.Y.; Du, J.J.; Cui, S.S.; Liu, J.; Lin, Y.Q.; He, Y.X.; Fu, Y.; Gao, C.; Li, G.; et al. Lack of Association Between DNMT3B Polymorphisms and Sporadic Parkinson's Disease in a Han Chinese Population. Neurosci. Bull. 2018, 34, 867-869. [CrossRef]

57. Erichsen, L.; Ghanjati, F.; Beermann, A.; Poyet, C.; Hermanns, T.; Schulz, W.A.; Seifert, H.H.; Wild, P.J.; Buser, L.; Kröning, A.; et al. Aberrant methylated key genes of methyl group metabolism within the molecular etiology of urothelial carcinogenesis. Sci. Rep. 2018, 8, 3477. [CrossRef]

58. Tang, Q.; Chen, Y.; Wu, W.; Ding, H.; Xia, Y.; Chen, D.; Wang, X. Idiopathic male infertility and polymorphisms in the DNA methyltransferase genes involved in epigenetic marking. Sci. Rep. 2017, 7, 11219. [CrossRef]

59. Liu, Y.; Zheng, H.; Guo, P.; Feng, S.; Zhou, X.; Ye, D.; Chen, X.; Chen, S. DNA methyltransferase 3A promoter polymorphism is associated with the risk of human spontaneous abortion after assisted reproduction techniques and natural conception. J. Assist. Reprod. Genet. 2017, 34, 245-252. [CrossRef]

60. Liu, C.H.; Tao, T.; Jiang, L.; Xu, B.; Zhang, L.; Lu, K.; Zhang, X.W.; Chen, S.Q.; Liu, D.C.; Chen, M. DNMT3A-448A>G polymorphism and cancer risk: A meta-analysis. Genet. Mol. Res. 2015, 14, 3640-3649. [CrossRef]

61. Ni, G.; Qin, J.; Chen, Z.; Li, H.; Zhou, J.; Huang, M.; Zhou, L. Associations between genetic variation in one-carbon metabolism and leukocyte DNA methylation in valproate-treated patients with epilepsy. Clin. Nutr. 2018, 37, 308-312. [CrossRef]

62. Sharma, T.K.; Vardey, S.K.; Sitaraman, S. Evaluate the Effect of Valproate Monotherapy on the Serum Homocysteine; Folate and Vitamin B12 Levels in Epileptic Children. Clin. Lab. 2015, 61, 933-940. [CrossRef]

63. Ni, G.; Qin, J.; Li, H.; Chen, Z.; Zhou, Y.; Fang, Z.; Chen, Y.; Zhou, J.; Huang, M.; Zhou, L. Effects of antiepileptic drug monotherapy on one-carbon metabolism and DNA methylation in patients with epilepsy. PLoS ONE 2015, 10, e0125656. [CrossRef]

64. Migheli, F.; Stoccoro, A.; Coppedè, F.; Wan Omar, W.A.; Failli, A.; Consolini, R.; Seccia, M.; Spisni, R.; Miccoli, P.; Mathers, J.C.; et al. Comparison study of MS-HRM and pyrosequencing techniques for quantification of APC and CDKN2A gene methylation. PLoS ONE 2013, 8, e52501. [CrossRef]

65. Coppedè, F.; Grossi, E.; Buscema, M.; Migliore, L. Application of artificial neural networks to investigate one-carbon metabolism in Alzheimer's disease and healthy matched individuals. PLoS ONE 2013, 8, e74012. [CrossRef]

(C) 2019 by the authors. Licensee MDPI, Basel, Switzerland. This article is an open access article distributed under the terms and conditions of the Creative Commons Attribution (CC BY) license (http://creativecommons.org/licenses/by/4.0/). 